\title{
Influence, Significance and Importance of Body Mass Index in Scientific Research and Various Fields of Science
}

\author{
Katarzyna Zygmunt ${ }^{1}$, Maciej Kuchciak ${ }^{2}$, Marcin Nycz ${ }^{3}$, Miłosz Szczudło ${ }^{4}$, and Gabriel Bobula*5 \\ ${ }^{1}$ Faculty of Medicine, Institute of Physiotherapy, University of Rzeszow, Poland \\ 2,5Faculty of Physical Education, University of Rzeszow, Poland \\ ${ }^{3}$ Margo-Fit Fitness Center, tańcut, Poland \\ ${ }^{4}$ Sport and Recreation Center, University of Rzeszow, Poland
}

*Corresponding author: Gabriel Bobula, Department of Physical Education, University of Rzeszow, Poland.

To Cite This Article: Gabriel Bobula. Influence, Significance and Importance of Body Mass Index in Scientific Research and Various Fields of Science. Am J Biomed Sci \& Res. 2019 - 4(4). AJBSR.MS.ID.000816. DOI: 10.34297/AJBSR.2019.04.000816

Received: August 01, 2019 | Published: August 12, 2019

\begin{abstract}
Modern generations of humans pay a lot of attention to a healthy lifestyle, and body mass index is the most popular determinant of health. This tool is used by all people, both amateur trainers, as well as professionals, scientists and researchers. It is used in gym, laboratory, medical office, home, just everywhere and by everyone. BMI indicator applies in different fields of science, trying to determine different aspects of its impact on physical, psychological and social aspects of life. This mini review presents selected examples of the use of body mass index in various fields of science by scientists from different countries.
\end{abstract}

Keywords: BMI; Body; Mass; Index; Indicator; Health; Research; Science

\section{Introduction}

Body mass index (BMI), otherwise known as the Quetelet II index from the Belgian founder Adolphe Quetelet (in the 19th century), is used to determine the body mass index by the body mass quotient expressed in kilograms ( $\mathrm{kg}$ ) by the square of body height expressed in square meters $(\mathrm{m} 2)$ :

Body mass index helps to estimate the risk of underweight and obesity of examined person. The phenomenon of obesity and underweight may be associated with the development of diseases classified as civilization diseases, such as diabetes, stroke, atherosclerosis, hypertension and nutrition disorders. The World Health Organization (WHO) has identified six ranges defining the state of the subject (Table 1).

Table 1: European nutritional status for adults over 20 years old.

\begin{tabular}{|c|c|}
\hline BMI & Nutritional Status \\
\hline$<18.5$ & Underweight \\
\hline $18.5-24.9$ & Normal weight \\
\hline $25.0-29.9$ & Pre-obesity \\
\hline $30.0-34.9$ & Obesity class I \\
\hline $35.0-39.9$ & Obesity class II \\
\hline $40.0<$ & Obesity class III \\
\hline
\end{tabular}

However, one of the most commonly used tools was created for adults. For children it is recommended to use centile grids. The downside of BMI is that it is impossible to distinguish muscle tissue from adipose tissue, which in athletes, especially in people practicing strength sports, can be misleading and misinterpreted [1]. The aim of the work is to present, through numerous publications, the comprehensive application of the Quetelet II index in various articles and fields of science.

\section{Body Mass index overview in Scientific Research}

Body mass index according to World Health Organization is commonly used tool in many different scientific fields. One of research area is disease prophylaxis, which concentrate on studies concerning morbidity risk in various disease, particularly civilization diseases. Authors engage in this problematic is articles where BMI rate used to determine obesity level in highly developed countries in Europe. Research results led into raising consciousness of increasing obesity tendency, and consequently, the need for introduction of prophylaxis and awareness raising programs regarding risks of wrong nutrition habits and their influence on BMI rate, in particularly exposed countries [2-7]. Different problematic was presented by Ohlsson and Bygdell, who described the correlation of 
increased BMI during the puberty phase and increased stroke risk in adulthood. Authors based on the research results, alarmed that young people, whose body mass index is increasing over the years, in future are in stroke risk group. These facts indicates the need for introducing action, which significantly reduce BMI or will help to maintain it on recommended level [8-12].

A very important aspect of use body mass index is the problem of diabetes. Research shows that high level of BMI has significant influence on its development, as well as keeping appropriate BMI value could stop and prevent the evolution of the disease [13-17]. Body Mass Index is also used in nutrigenomics, a branch of science which is focused on influence of nutrients on genes expression and metabolic changes. Authors of this works are mainly focusing on correlations between gene polymorphisms and BMI index, which are closely connected with development of civilization diseases like type II diabetes and obesity. With regard to articles related to human health issues its worth to mention about physiology and their works, where by BMI level is used for indicating, overweight and obesity, especially abdominal obesity which are common in women in reproductive age and development of this disability show increasing tendency along with age. Other physiological aspect is the relation between BMI and human bacterial flora [18-21]. It's worth to mention about biomechanical sciences with the researches being conducted focusing on the correlations between the BMI and bone density and structure, as well as the forces acting on joints during movement [22-26].

Regarding to anthropological studies, authors used BMI in diagnosis as applicability range in kids and youths, presents restrictions of BMI rate, as well as using anthropometric survey to prediction where is measurement of body mass index. It is valuable in modern sport science, where the researchers are evaluating the correlations between the body mass index and physical fitness and activity in different groups [27-32].

\section{Conclusions}

The Body mass index allows to determine the state of nutrition through mathematical calculations obtained on the basis of anthropometric measurements of height and body weight. It is an indicator used in various fields of science from anthropology, through diabetology, sports science, and even with nutrigenomics. Its use allows to determine the state of nutrition or disorders occurring in it, which in turn is a reference to various aspects of scientific research. The body mass index, however, does not always reflect the reality to the right degree. It should not be used in the traditional form in the case of children or people with an athletic figure. In case of children, modified calculation formula of the indicator should be used, while for athletes it have to be interpreted very carefully.

\section{References}

1. Body mass index - BMI. World Health organization
2. Kędzior A, Jakubek-Kipa K, Brzuszek M, Mazur A (2017) Trendy w występowaniu nadwagi i otyłości u dzieci na świecie w Europie iw Polsce. Endokrynol Ped 1(58): 41-48.

3. Lakerveld J, Rebah M B, Mackenbach, J D Charreire H, Compernolle S, et al. (2015) Obesity-related behaviours and BMI in five urban regions across Europe: sampling design and results from the SPOTLIGHT cross-sectional survey. BMJ open 5(10): 1-9.

4. Bleich SN, Vercammen KA, Zatz LY, Frelier JM, Ebbeling CB, et al. (2018) Interventions to prevent global childhood overweight and obesity: a systematic review. The Lancet Diabetes \& Endocrinology 6(4): 332-346.

5. Geserick M, Vogel M, Gausche R, Lipek T, Spielau U, et al. (2018) Acceleration of BMI in early childhood and risk of sustained obesity. The New England Journal of Medicine 379(14): 1303-1312.

6. Adab P, Pallan M, Whincup PH (2018) Is BMI the best measure of obesity University of Birmingham 360: 1-2.

7. Buscot MJ, Thomson RJ, Juonala M, Sabin M, A Burgner DP, et al. (2018) BMI trajectories associated with resolution of elevated youth BMI and incident adult obesity. Pediatrics, 141(1): 1-12.

8. Ohlsson C, Bygdell M, Sondén A, Jern C, Rosengren A, et al. (2017) BMI increase through puberty and adolescence is associated with risk of adult stroke. Neurology 89(4): 363-369.

9. Adjah ES O, Ray KK, Paul SK (2019) Ethnicity-specific association of BMI levels at diagnosis of type 2 diabetes with cardiovascular disease and all-cause mortality risk. Acta diabetologica 56(1): 87-96.

10. Huang RC, Lillycrop KA, Beilin LJ, Godfrey KM, Anderson D, et al. (2019) Epigenetic Age Acceleration in Adolescence Associates With BMI, Inflammation, and Risk Score for Middle Age Cardiovascular Disease. The Journal of Clinical Endocrinology \& Metabolism, 104(7): 3012-3024.

11. Antonopoulos AS, Oikonomou EK, Antoniades C, Tousoulis D (2016) From the BMI paradox to the obesity paradox: the obesity-mortality association in coronary heart disease. Obes Rev 17(10): 989-1000.

12. Mongraw-Chaffin ML, Peters SA, Huxley RR, Woodward M (2015) The sex-specific association between BMI and coronary heart disease: a systematic review and meta-analysis of 95 cohorts with $1 \cdot 2$ million participants. Lancet Diabetes Endocrinol 3(6): 437-449.

13. Ferrara CT, Geyer SM, Liu YF, Evans-Molina C, Libman IM, et al. (2017) Excess BMI in childhood: a modifiable risk factor for type 1 diabetes development? Diabetes care 40(5): 698-701.

14. Han TS, Al-Gindan YY, Govan L, Hankey CR, Lean ME (2019). Associations of BMI, waist circumference, body fat, and skeletal muscle with type 2 diabetes in adults. Acta Diabetol 56(8): 947-954.

15. Srinivasan S, Jablonski KA, Knowler WC, Dagogo-Jack S, Kahn S, et al. (2019) A polygenic lipodystrophy genetic risk score characterizes risk independent of BMI in the Diabetes Prevention Program. Journal of the Endocrine Society

16. Geng T, Smith CE, Li C, Huang T (2018) Childhood BMI and adult type 2 diabetes, coronary artery diseases, chronic kidney disease, and cardiometabolic traits: A Mendelian randomization analysis. Diabetes care 41(5): 1089-1096.

17. Hammoud NM, de Valk, HW, van Rossem L, Biesma DH, et al. (2017) Growth and BMI during the first $14 \mathrm{y}$ of life in offspring from women with type 1 or type 2 diabetes mellitus. Pediatric research Pediatr Res 81(2): 342-348.

18. Ohlsson C, Bygdell M, Nethander M, Rosengren A, Kindblom JM, eta 1 . (2018) BMI change during puberty is an important determinant of adult type 2 diabetes risk in men. J Clin Endocrinol Metab 104(5): 1823-1832.

19. Koszowska A, Ebisz M (2015) Rozwój nauk o żywności i żywieniu—od norm żywienia do genomiki żywienia. Forum Zaburzeń Metabolicznych 6(3): 85-93. 
20. Szostak-Wegierek D, Waskiewicz, A (2015) Metabolic disorders in women at procreative age living in Warsaw. Rocz Panstw Zakl Hig 66(3): 245251.

21. Ottosson F, Brunkwall L, Ericson U, Nilsson PM, Almgren P, et al. (2018) Connection between BMI-related plasma metabolite profile and gut microbiota. J Clin Endocrinol Metab 103(4): 1491-1501.

22. Rivera M, Rovira P, Cervilla J, Ching-López A, Martín-Laguna, et al. (2017) The VAL66MET Bdnf Genetic Polymorphism Does Not Modify The Association Between Major Depression And Body Mass Index (BMI). European Neuropsychopharmacology 27(3): S447.

23. Shen J, Nielson CM, Marshall LM, Lee DC, Keaveny, et al. (2015) The Association Between BMI and QCT-Derived Proximal Hip Structure and Strength in Older Men: A Cross-Sectional Study. J Bone Miner Res 30(7): 1301-1308.

24. Mei Q, Fernandes J, Hume P, Gu, Y (2016) Investigating biomechanical function of toes through external manipulation integrating analysis. Acta Bioeng Biomech 18(1): 97-102.

25. Sompalli S, Singh P, Naumann D, Covassin N, Somers VK, et al. (2019) Bone Mineral Density in Obstructive Sleep Apnea and Obesity. THE FASEB JOURNAL 33(1): 551-524.

26. Costa de Miranda R, Di Lorenzo N, Andreoli A, Romano L, Lou de Santis GL, et al. (2019) Body composition and bone mineral density in Huntington's disease. Nutrition 59: 145-149.
27. Webster J, Vajravelu ME, Choi C, Zemel B, Verma R, eta l. (2019) Prevalence of and Risk Factors for Low Bone Mineral Density in Children With Celiac Disease. Clin Gastroenterol Hepatol 17(8): 1509-1514.

28. Stupnicki R (2015) Relacje wagowo-wzrostowe i stosowanie wskaźnika BMI u dzieci i młodzieży. Zeszyty Naukowe WSKFiT 10: 41-47.

29. Junger J, Frömel K, Bergier J, Ács P, Bergier, et al. (2018) Physical activity in students from the Visegrad countries by BMI status. Health Problems of Civilization 12(1): 41-48.

30. Nikolaidis PT, Chtourou H, Torres-Luque G, Rosemann T, Knechtle B, et al. (2019) The Relationship of Age and BMI with Physical Fitness in Futsal Players Sports 7(4): 87.

31. Ploch C, Thomas DM, Adams B, Turner D, Hug A, et al. (2019) Prediction of cadet basic training physical performance outcomes. The FASEB Journal 3(1): 693-617.

32. Walsh D, Belton S, Meegan S, Bowers K, Corby D, et al. (2018) A comparison of physical activity, physical fitness levels, bmi and blood pressure of adults with intellectual disability, who do and do not take part in special olympics ireland programmes: Results from the sophie study. J Intellect Disabil 22(2): 154-170. 